\title{
Analysis of Correlation between Toluene Exposure and Health Risk Characterization on Printing Worker of Plastic Bags Industry
}

\author{
Jihan Faradisha ${ }^{1}$, Abdul Rohim Tualeka1, Noeroel Widajati', Mulyonor \\ ${ }^{1}$ Departement of Occupational Health and Safety, Faculty of Public Health, Airlangga University, \\ Surabaya, Indonesia; The Indonesian Association of Occupational Health and Safety, Jakarta Pusat, Indonesia
}

\begin{abstract}
The production process of plastic bag industry have always hazards and risks. Chemicals is one of the hazard that used in this industry. That is toluene, one of chemicals used in printing process. Toluene can cause several occupation health risk and effect. This study aimed to determine the correlation of toluene exposure and health risk characterization (RQ) in printing workers PT X Sidoarjo. This study was an observational study with cross-sectional approach. The sample in this study was a total of 32 respondent. The concentration of toluene measured by using gas chromatography as the instrument. The health risk characterization (RQ) calculated by dividing intake dose value with reference concentration. The result showed the concentration of toluene in location 2 was $31,54 \mathrm{ppm}$ and above threshold limit value based on ACGIH (2011). There was $40,6 \%$ printing workers had $\mathrm{RQ} \geq 1$ and there was a significant correlation between toluene exposure and health risk characterization (RQ).
\end{abstract}

Keyword: toluene, health risk characterization, printing worker, plastic bag industry

\section{Introduction}

The production process of plastic bag industry have always hazards and risks. Chemicals is one of the hazard that used in this industry. One of the hazardous chemicals used in the plastic bags industry is toluene. Toluene is usually used as a solvent of paint on the printing process of plastic bags. Toluene is a volatile, colorless and commonly used as a paint solvent, a mixture of gasoline, nail polish, and as a solvent in the printing business. Workers using toluene as a solvent could have health problems, such as dizziness, vertigo, eye irritation, skin irritation, respiratory problems, liver, kidney, and central nervous system disorders. ${ }^{1,2}$

\section{Corresponding Author:}

Dr. Abdul Rohim Tualeka

Departement of Occupational Health and Safety, Faculty of Public Health, Airlangga University, Surabaya, Indonesia Email: inzut.tualeka@gmail.com
Toluene entry into the body can be through 3 paths, in addition to the main path of inhalation, toluene can enter the body through the path of ingestion and skin contact. Toluene is declared safe for the environment and health if it does not cross the threshold. According to ACGIH (2011) the threshold limit value of toluene is $20 \mathrm{ppm}$ for 8 hours/day 40 hours per week. ${ }^{3,4}$

Some cases of toluene exposure recorded inATSDR (2015) include study by Yin et al (1987) reported by 44 men and 57 women exposed to TWA concentrations of 46 and $41 \mathrm{ppm}$ toluene repetitively, during shoe-making, printing and audio equipment increased complaints headaches, dizziness and difficulty sleeping compared with 127 control groups. Similarly, the study by Ukai et al (1993) reported an increase in subjective complaints against neurologic symptoms both during and after work in 452 workers exposed toluene (geometric mean 24.7 ppm) compared with 517 control groups.'

This study aimed to determine the correlation of toluene exposure and health risk characterization (RQ) in printing workers to see if toluene exposure has a health effecton the worker's body. 


\section{Material and Method}

This study aimed to determine the correlation of toluene exposure and health risk characterization(RQ) in printing workers PT X Sidoarjo. This study was an observational study with cross-sectional approach. The sample in this study was a total of 32 printing workers. The concentration of toluene measured by using gas chromatography as the instrument. The health risk characterization (RQ) calculated by dividing intake dose value with reference concentration.

\section{FINDINGS}

\section{The Concentration of Toluene}

Table 1: The Frequency Distribution of Toluene

\begin{tabular}{|c|c|c|c|}
\hline Location & The Concentration of Toluene (ppm) & Printing Workers & Percentage \\
\hline Location 1 & 8.930 & 8 & 25,0 \\
\hline Location 2 & 31.546 & 11 & 34,4 \\
\hline Location 3 & 9.677 & 6 & 18,8 \\
\hline Location 4 & 9.530 & 7 & 21,9 \\
\hline Mean & \multicolumn{2}{|c|}{14.92} \\
\hline Min-Max & \multicolumn{2}{|c|}{$8.93-31.54$} \\
\hline
\end{tabular}

Table 1 showed the concentration of toluene in 4 location. The lowest concentration of toluene is 8,93 ppm and the highest concentration of toluene is 31,54 ppm. This highest concentration can caused by some pile of toluene cans at Location 2 while measuring the concentration of toluene.

The Health Risk Characterization (RQ)

Table 2: The Frequency Distribution of Health Risk Characterization

\begin{tabular}{|c|c|c|}
\hline Variable & Category & Percentage (\%) \\
\hline Risk & $\mathrm{RQ} \geq 1$ & $40,6 \%$ \\
\cline { 2 - 3 } Characterization & $\mathrm{RQ}<1$ & $59,4 \%$ \\
\hline
\end{tabular}

The results of Risk Quotients (RQ) calculations show the level of health risk due to exposure to toluene in the work environment. If $\mathrm{RQ} \geq 1$, this means the printing workers exposed to toluene exposure has health risk effects and if $\mathrm{RQ}<1$, this means the printing workers exposed to toluene exposure has no health risk effects. $5,6,7$ Table 2 showed that $40,6 \%$ printing workers has health risk effects caused by toluene exposure and $59,4 \%$ printing workers has no health risk effects.

The Correlation Between Toluene Exposure and Health Risk Characterization

Table 3. The correlation between toluene exposure and Risk Characterization

\begin{tabular}{|c|c|c|c|}
\hline \multirow{2}{*}{$\begin{array}{c}\text { Toluene } \\
\text { Concentration (ppm) }\end{array}$} & \multicolumn{2}{|c|}{ Percentage } & \multirow{2}{*}{$\begin{array}{c}\mathbf{P} \\
\text { Value }\end{array}$} \\
\hline & $R Q \geq 1$ & $\mathrm{RQ}<1$ & \\
\hline 8,93 & $0 \%$ & $100 \%$ & \multirow{4}{*}{0,00} \\
\hline 31,54 & $90,9 \%$ & $9,1 \%$ & \\
\hline 9.53 & $14,3 \%$ & $85,7 \%$ & \\
\hline 9,67 & $33,3 \%$ & $66,7 \%$ & \\
\hline
\end{tabular}

Table 3 showed the highest percentage $90,9 \%$ printing workers in Location 2 (31,54ppm) has RQ $\geq 1$. The correlation between toluene exposure and RQ has a significant correlation with the p-value is 0,00 .

\section{Discussion}

The Concentration of Toluene: The result showed one of all printing locations has the concentration of toluene above the TLV. ${ }^{3}$ The result of study in informal workshop Karasak showed that the average of toluene concentration is $71,29 \mathrm{ppm} .{ }^{8}$ Study in paint industry in Iran showed the concentration of toluene is $105,82 \mathrm{ppm}^{9}$ Another study in printing company in Jakarta showed that the concentration of toluene is $100,38 \mathrm{ppm} .{ }^{10}$

The amount of exposure to toluene vapor depends on the work place (opened or closed), and physical factors, such as wind direction, temperature, humidity, and air pressure. Based on the observation in the workplace, the location of printing process is a closed hall and has 12 blowers near all printing location. With the temperature about $30^{\circ} \mathrm{C}$ toluene will more easily evaporate in the air.

Workers who use toluene as a solvent may have health problems, such as dizziness, vertigo, eye irritation, skin irritation, respiratory problems, liver, kidney, and central nervous system disorders. Toluene exposure can lead to acute and chronic poisoning symptoms. The early acute poisoning symptomps have been observed in experimental study conducted volunteers with the concentration of toluene about $750 \mathrm{mg} / \mathrm{m}^{3}$ for 8 hours or $1.125 \mathrm{mg} / \mathrm{m}^{3}$ for 20 minutes may cause respiratory irritation and eye irritation. 
Furthermore the chronic poisoning symptomps may appear with the concentration levels about $200-400 \mathrm{mg} /$ $\mathrm{m}^{3}$ continuously for 8 hours every day or 40 hours a week. The concentrations of toluene above the threshold limit value may cause neuropsychological symptoms, as the study by Darwati (2004) the results showed that workers exposed to toluene exposure have a 7,12 times higher neuropsychological symptoms compared with workers not exposed to toluene exposure. ${ }^{1,11}$

The Health Risk Characterization: The results of Risk Quotients (RQ) calculations showed 40,6\% printing workers have $R Q \geq 1$ which means the printing workers have health risk effects due to toluene exposure. Another study by Prihartini (2010) showed $8 \%$ of respondents in finishing process have $R Q \geq 1$, this may caused by the finishing location has the concentration of toluene higher than other location. ${ }^{12}$

Based on the result, every location has its own health risk effects depends on the level of toluene concentration, the result of calculations showed that the higher toluene concentration the higher health risk effects in the work environment.

1. Location 1: Location 1 has $R Q<1$ which means printing workers has no health risk effects due to toluene exposure. Several factors influence the $\mathrm{RQ}$ value such as the concentration of toluene, worker's weight and worker's working period. The concentration of toluene at location 1 is lower than that of other sites, that is $8,93 \mathrm{ppm}$.

Based on observation, most of printing workers in Location 1 is not wearing protection equipment such as mask and gloves, in view of the most absorption of toluene is through respiration then skin contact and oral, printing workers may have more risk to have health effects caused by toluene exposure when they are not wearing standard personal protective equipment.

2. Location 2: Location 2 has $R Q \geq 1$ which means printing workers have health risk effects due to toluene exposure. This result showed that toluene exposure may cause adverse health effect which needs risk control to reduce the health eff ects. Near to location 2 there are some pile of toluene cans for production process, to reduce the concentration of toluene in location 2, it needs to rearrange it. Moreover, it needs to have ventilation for air exchanges. There was $9,1 \%$ printing worker have $\mathrm{RQ}<1$ this can be caused by working period that only about a year until the study.

3. Location 3: There were $85,7 \%$ printing workers have RQ $<1$ which means printing workers have no health risk effects due to toluene exposure and $14,3 \%$ printing workers have $R Q \geq 1$ which means printing workers have health risk effects due to toluene exposure. Working period of $14,3 \%$ printing workers influence the value of RQ. Study by Lundberg in Gamble (2000) workers with at least 10 years of work with high levels of organic solvent exposure have an adverse health risk. Lundberg also believes a 10 -yearwork period with organic solvent exposure is considered a criterion for diagnosing chronic toxic encelopathy. ${ }^{13}$ Furthermore one printing worker in this category has excess body weight. Toluene compounds are lipophilic (fat soluble) the fat will bind toluene into residue in the body. In other words, the more obese respondents exposed toluene it will have a health risk higher due to toluene exposure.

4. Location 4: There were $66,7 \%$ printing workers hav RQ $<1$ which means printing workers have no health risk effects due to toluene exposure and $33,3 \%$ printing workers have $R Q \geq 1$ which means printing workers have health risk effects due to toluene exposure. Working period of $14,3 \%$ printing workers influence the value of RQ. By this condition, not only the concentration of toluene, weight and working period influence the RQ value, but there are some factors such foods (some foods may influence the absorption of toluene), life style and others.

The Correlation Between Toluene Exposure and Risk Characterization: The result showed that there was significant relationship between toluene exposure and risk characterization. Study in shoe craftmans worker showed that the workers exposed to toluene exposure have health risk effects, $20 \%$ workers have headache, $18,2 \%$ workers fatigue and $18,8 \%$ workers caugh. ${ }^{14}$ Other study in gas station in Thailand showed that the workers have RQ $\geq 1,61 \%$ workers have headache, $29 \%$ workers fatigue and $11 \%$ workers throat irritation. ${ }^{15}$ Study by Martha (2012) on sole shoe worker at Cibaduyut Bandung, where the most content of glue compound contained is toluene, many workers have 
health complaints synonymous with toluene exposure symptoms, including dizziness, nausea, weakness and shortness of breath. ${ }^{16}$

Based on interview $31,3 \%$ printing workers have headache and $37,5 \%$ workers fatigue. At exposure close to $50 \mathrm{ppm}$ will occur symptoms of drowsiness and headache. At concentrations of 50-100 ppm will occur irritation of the nose, throat and respiratory tract. At concentration of about $100 \mathrm{ppm}$ may cause fatigue (fatigue) and dizziness. ${ }^{1}$

One effort that can be done to reduce health risk effects is to reduce the concentratiom of toluene in the air. Thus, the toluene vapor inhaled by the workers will also decrease its concentration so as to minimize the health risk effects due to toluene exposure. To minimize the health risk effects caused by toulene exposure, the management can make a good ventilation system so that toluene vapor can be distributed with the air outside the production area. Toluene is a volatile compound, with a good ventilation the concentration of toluene in the printing location can be reduced. And the last thing can be done is to wear standard personal protective equipment, management must have the standard personal protective equipment and give it free to the workers. Beside that, management have to inform the workers about the hazard of toluene and advise the workers to wear personal protective equipment during work.

\section{Conclusion}

1. From the four location of toluene measurement obtained the lowest concentration of toluene is $8.93 \mathrm{ppm}$ and the highest concentration of toluene is 31.54 . The level of concentration in each location causes different levels of risk for the workers

2. The results of Risk Quotients (RQ) calculations $40,6 \%$ printing workers have health risk effects caused by toluene exposure and 59,4\% printing workers have no health risk effects

3. There was a significant correlation between toluene exposure and health risk characterization

\section{Conflict of Interest: None}

Source of Funding: Self funding
Ethical Clearance: This study was approved by Health Research Ethics Committee, Faculty of Public Health, Airlangga University

\section{REFERENCES}

1. ATSDR. Toxicological Profile For Toluene. US Departemen. United States. 2015

2. WHO. Air Quality Guideliness : Chapter 5.14 Toluene. WHO Regional Office for Europe. Copenhagen. Denmark. 2000.

3. American Conference of Govermental Industrial Hygienists. TWV s and BEIs for Chemical Substance and Physical Agents. Cincinnati. Ohio. 2011

4. EPA. Integrated Risk Information System. United States. 2005. Available from : https://cfpub.epa. gov/ncea/iris2/chemicalLanding.cfm?substance_ $\mathrm{nmbr}=118$

5. Rahman. Analisis Risiko Kesehatan Lingkungan Pertambangan Kapur di Sukabumi, Cirebon, Tegal, Jepara dan Tulung Agung. 2008. Jurnal Ekologi Kesehatan 7 (1), p. 665-677

6. Tualeka, A.R. (2013). Toksikologi Industri. Surabay : Graha Ilmu Mulia

7. Louvar, J.F. and Louvar, B.D. Health and Environmental Risk Analysis: Fundamentals with Aplication, Volume 2, New Jersey, Prentice Hall PTR. 1998

8. Ekaputri, S. Hubungan Paparan Toluen Dengan Kadar Asam Hipurat Urin Pekerja Pengecatan Mobil (Studi pada Bengkel Mobil Informal di Karasak, Kota Bandung), tesis. Program Studi Magister Teknik Lingkungan. Fakultas Teknik Sipil dan Lingkungan Institut Teknologi Bandung. 2012

9. Jafari, M.J., Karimi, A., Azari, M.R. The Rule of Exhaust Ventilation in Reducing Occupational Exposure to Organic Solvent in a Paint Manufacturing Company. 2008. Indian Journal of Occupational and Environmental Medicine 12 (2), p. 82-87.

10. Sophianita. Hubungan antara kadar asam hipurat urin akibat pajanan toluen dengan efek kesehatan akut pada tenaga kerja percetakan "X", tesis, Fakultas Kedokteran Universitas Indonesia. 2003. 
11. IPCS. Toluene : Environmental Health Criteria 52. WHO. Genewa. 1986.

12. Prihartini, N. Analisis Risiko Kesehatan Pajanan Toluen Pada Pekerja Bengkel Sepatu X Di Kawasan Perkampungan Industri Kecil (PIK) Pulogadung, tesis. Program Pascasarjana Fakultas Kesehatan Masyarakat. Universitas Indonesia. 2010.

13. Gamble, J. Low-level hydrocarbon solvent exposure and neurobehavioral effect. 2000. Occupational Medicine 50, p. 81-102.

14. Maryiantari, E.S., Martiana, T., Sulistyorini, L. Analyse the level of Health Risk From Exposure
To Toluene In Shoes Craftsman Workers. 2016. American Scientific Research Journal 16 (1).

15. Tunsaringkarn T., Siriwong W., Rungsiyothin A., and Nopparatbundit S. Occupational Exposure of Gasoline Stasion Worker to BTX Compounds in Bangkok, Thailand. 2012. The National Journal of occupational and Environmental Medicine, Vol 13 Number 3, p. 117-25.

16. Marta, T. H. Hubungan Pa janan Senyawa Benzena, Toluena dan Xilena Dengan Sistem Hematologi Pekerja di Kawasan Industri Sepatu. tesis. Program Magister Teknik Lingkungan. Fakultas Teknik Sipil Institut Teknologi Bandung. 2012. 